\title{
Allyl type monomers for hard surface coating protection
}

\author{
Larisa Popova ${ }^{1 *}$, Anzhelika Tsyrulnikova ${ }^{2}$, Sergey Vershilov ${ }^{2}$, Julia Bazarnova ${ }^{1}$, Ekaterina Aronova ${ }^{1}$, and Ludmila \\ Osetrova $^{2}$ \\ ${ }^{1}$ Peter the Great St. Petersburg Polytechnic University, St. Petersburg, Russian Federation \\ ${ }^{2}$ S.V. Lebedev Research Institute of Synthetic Rubber, St. Petersburg, Russian Federation
}

\begin{abstract}
Based on the unsaturated derivatives of polyfluoroalkanols chemical products are used to protect solid and fibrous materials surface from the effects of water, oils and other pollutants. A method for obtaining allyl ethers of polyfluoroalkanols (polyfluoroalkoxypropenes) is based on the Williamson ether reaction. This method is a heterophase process. The use of solvents to improve mass transfer requires complementary measures to ensure industrial and environmental safety. It is more preferable to obtain the target ethers in water with PTC. A series of experiments using different chain length polyfluoroalkanols was studied by GLC. Kovats retention indexes of the target ethers were determined. It was found that in the case of lower homologues $\left(\mathrm{CF}_{3} \mathrm{CH}_{2} \mathrm{OH},\left(\mathrm{CF}_{3}\right)_{2} \mathrm{CHOH}, \mathrm{HCF}_{2} \mathrm{CF}_{2} \mathrm{CH}_{2} \mathrm{OH}\right)$, the addition of 5-15 vol.\% 1,4-dioxane as a solubilizer provides a high yield of products. The application of PTC (tetrabutylammonium bromide) is indispensable for using polyfluoroalkanols with a longer carbon chain $(\mathrm{C} \geq 5)$. PTC invariably provides the almost complete conversion of polyfluoroalkanols. The decomposition process of TBAB becomes noticeable (GLC method) upon completion of the main reaction. Polyfluoroalkoxypropenes form azeotrope with water, which can be used in the work up process.
\end{abstract}

\section{Introduction}

Protection of surface against water, oil, as well as pollution of various origins allows increasing the period of use of such object and improving its appearance and consumer properties. Such protection is successfully applied both in the traditional (construction, textile, paper and cardboard manufacturing, etc.) [1-4] and in the latest (optics, microelectronics, information storage systems, etc.) [5-7] technologies.

Some organic compounds with a high fluorine content provide better protection due to their unique chemical and physicochemical properties [8]. Despite the high cost of organofluorine products, their areas of use are constantly expanding [9-11].

Polymer materials based on the derivatives of polyfluoroalkanols and containing an unsaturated fragment (acrylates, maleates, vinyl, and allyl ethers) have been actively studied for the past several decades. Acrylates and methacrylates of some polyfluoroalkanols are already commercial products. Allyl (and vinyl) ethers of polyfluoroalkanols appear to be less developed. Scientific works involved these compounds, however, has not stopped since the first reports related to the mid1960s [12-15].

The Williamson ether reaction (the interaction of fluoroalkanols with allyl halides (chlorides, bromides) in the presence of base) is primarily the basis for the synthesis of polyfluoroalkoxypropenes. A detailed review of the original literature showed a great variety of synthesis routes. They are discussed in more detail below. In our view, the use of organic solvents under the conditions of a heterophase process can be acceptable only on a laboratory scale. In industrial production, the use of flammables and toxic solvents requires additional safety measures, including environmental ones. The process is also heterophase in aqueous medium. A phase transfer catalyst (PTC) of the type of quaternary ammonium salts is used to improve mass transfer [16, 17].

We established earlier that in the case of lower fluoroalkanols $\quad\left(\mathrm{CF}_{3} \mathrm{CH}_{2} \mathrm{OH}, \quad\left(\mathrm{CF}_{3}\right)_{2} \mathrm{CHOH}\right.$, $\mathrm{HCF}_{2} \mathrm{CF}_{2} \mathrm{CH}_{2} \mathrm{OH}$ ), high conversion is achieved when a small amount of 1,4-dioxane is used as a solubilizer [18].

One of the objectives of this research work, aimed at the developing of a practical method for producing polyfluoroalkoxypropenes, was to establish the interconnection between the chain length of polyfluoroalkanol and the need to use PTC in the Williamson ether reaction.

\footnotetext{
*orresponding author: lorapopova@mail.ru
} 


\section{Methods}

\subsection{General}

NMR spectra were recorded on a Bruker AM-500 $(500.13 \mathrm{MHz} 1 \mathrm{H} ; 470.56 \mathrm{MHz} 19 \mathrm{~F})$ spectrometer. $1 \mathrm{H}$ and 19F NMR spectra were obtained using deuterated solvents $\mathrm{CDCl} 3$ and DMSO-d6. (CH3)4Si was used as the internal standard; C6F6 - the external one. IR spectra were obtained on Spectrum 100, BTIR (broken total internal reflection). Spectral data were processed with the software ACD/SpecManager Version: 10.8.0.20701, 2008.

Gas chromatographic analysis of reaction mixtures and reaction products was performed on a Perkin Elmer chromatograph with a thermal conductivity detector and packed column (1.8 m x $3.175 \mathrm{~mm}$ i.d, from USA, stationary phase OV-215 (15\%) on W-AW-DMCS chromosorb; gas carrier (He), flow rate $10 \mathrm{ml} / \mathrm{min}$; split ratio $10: 1$. The temperature of a vaporizer and detector was $250^{\circ} \mathrm{C}$. The temperature program was $40^{\circ} \mathrm{C}, 0 \mathrm{~min}$; $20^{\circ} \mathrm{C} / \mathrm{min}$ to $250^{\circ} \mathrm{C}, 10 \mathrm{~min}$. All the chromatograms were processed using the software MultiChrom Version 3.4.00064, 2010.

The freshly distilled allyl bromide (I) (b.p. $=71.3^{\circ} \mathrm{C}$, $\mathrm{d}=1.390 \mathrm{~g} / \mathrm{cm}^{3}$ at $20^{\circ} \mathrm{C}$ ) and the fluoroalkanols were used at this research: 2,2,2-trifluoroethanol (a) (b.p. = $74^{\circ} \mathrm{C}, \quad \mathrm{d}=1.393 \mathrm{~g} / \mathrm{cm}^{3}$ at $\left.20^{\circ} \mathrm{C}\right), 1,1,1,3,3,3-$ hexafluoroisopropanol (b) (b.p. $=59^{\circ} \mathrm{C}, \mathrm{d}=1.605 \mathrm{~g} / \mathrm{cm}^{3}$ at $20^{\circ} \mathrm{C}$ ), $1 \mathrm{H}, 1 \mathrm{H}$-nonafluoropentanol (c) (b.p. $=110^{\circ} \mathrm{C}, \mathrm{d}$ $=1.664 \mathrm{~g} / \mathrm{cm}^{3}$ at $20^{\circ} \mathrm{C}$ ), 2,2,3,3-tetrafluoropropanol (d) (b.p. $=109.5^{\circ} \mathrm{C}, \mathrm{d}=1.471 \mathrm{~g} / \mathrm{cm}^{3}$ at $20^{\circ} \mathrm{C}$ ), $\alpha, \alpha, \omega-$ trihydroperfluoropentanol (e) (b.p. $=140.5^{\circ} \mathrm{C}, \mathrm{d}=1.667$ $\mathrm{g} / \mathrm{cm}^{3}$ at $20^{\circ} \mathrm{C}$ ), $\alpha, \alpha, \omega$-trihydroperfluoroheptanol (f) (b.p. $=171.8^{\circ} \mathrm{C}, \mathrm{d}=1.753 \mathrm{~g} / \mathrm{cm}^{3}$ at $\left.20^{\circ} \mathrm{C}\right), \alpha, \alpha, \omega-$ trihydroperfluorononanol (g) (m.p. $=66^{\circ} \mathrm{C}$, b.p. $=$ $\left.200^{\circ} \mathrm{C}\right)$.

\subsection{Synthesis of 3-polyfluoroalkoxypropenes}

\subsubsection{General procedure for preparing 3- polyfluoroalkoxypropenes (method A)}

Fluoroalkanol and 5-10 $\mathrm{ml}$ of 1.4-dioxane was added to a solution of $20-30 \mathrm{~g}$ (0.35-0.55 mol) of potassium hydroxide dissolved in water $(60-95 \mathrm{ml})$. The mixture was heated to $50-60^{\circ} \mathrm{C}$ and kept at this temperature for one hour. Allyl bromide was then added dropwise over 45-60 minutes, preventing the formation of the intense reflux in a condenser. The reaction mixture was kept with constant stirring for $4-13$ hours $\left(50-90^{\circ} \mathrm{C}\right)$. The organic layer was separated, washed with water until neutral according to a universal indicator. Any remaining allyl bromide was removed by treatment with $\mathrm{Na}_{2} \mathrm{SO}_{3}$ $\left(\mathrm{Na}_{2} \mathrm{SO}_{3} \cdot 7 \mathrm{H}_{2} \mathrm{O}\right) 15-30 \mathrm{~g}$ dissolved in water $(100 \mathrm{ml})$, and the mixture was stirred for $4 \mathrm{hr}$ at $60-90^{\circ} \mathrm{C}$. The organic phase was then separated, washed with water, dried with anhydrous $\mathrm{MgSO}_{4}\left(\mathrm{Na}_{2} \mathrm{SO}_{4}\right)$ and filtered. The remaining material was purified by simple distillation or azeotropic distillation with water to give the target products (3-polyfluoroalkoxypropenes) in 66-
$85 \%$ yields. The reaction conditions are presented in Table 1.

Table 1. 3-Polyfluoroalkoxypropenes (allyl fluoroalkyl ethers) synthesis by method A

\begin{tabular}{|c|c|c|c|c|c|}
\hline $\begin{array}{l}\text { Allyl } \\
\text { ether }\end{array}$ & $\begin{array}{c}\text { Allyl } \\
\text { bromide, } \\
\text { g (mol) }\end{array}$ & $\begin{array}{l}\text { Fluoro- } \\
\text { alkanol, } \\
\text { g (mol) }\end{array}$ & $\begin{array}{c}\text { Allyl } \\
\text { bromide: } \\
\text { fluoro- } \\
\text { alkanol }\end{array}$ & $\begin{array}{c}\tau, \\
\text { hr }\end{array}$ & $\begin{array}{l}\mathrm{T}, \\
{ }^{\circ} \mathbf{C}\end{array}$ \\
\hline Ia & $60.5(0.5)$ & $50(0.5)$ & $1: 1$ & 7 & $50-80$ \\
\hline $\mathrm{Ib}$ & $39(0.32)$ & $54(0.32)$ & $1: 1$ & 4 & $50-80$ \\
\hline Ic & $60.5(0.5)$ & $125(0.5)$ & $1: 1$ & 13 & 60-90 \\
\hline Id & $26.6(0.22)$ & $26(0.2)$ & $1.1: 1$ & 7 & $60-90$ \\
\hline Ie & $39.3(0.33)$ & $69.6(0.3)$ & 1.1:1 & 8 & $60-90$ \\
\hline If & $50(0.33)$ & $99.6(0.3)$ & $1.1: 1$ & 12 & $65-90$ \\
\hline
\end{tabular}

3-(2,2,2-Trifluoroethoxy)propene (Ia) was obtained as a colorless liquid $54.6 \mathrm{~g}(78 \%)$; b.p. $75^{\circ} \mathrm{C} .{ }^{1} \mathrm{H}$ NMR spectrum, $\delta$, ppm: 3.75-3.81 (q, $J=8.7 \mathrm{~Hz}, 2 \mathrm{H}, \mathrm{C}^{5} \mathrm{~F}_{3}-$ $\mathrm{C}^{4} \mathrm{H}_{2}$ ), 4.10 (d, $J=5.6 \mathrm{~Hz}, 2 \mathrm{H}, \mathrm{O}-\mathrm{C}^{3} \mathrm{H}_{2}$ ), 5.23 (d, $J=10.8$ $\left.\mathrm{Hz}, 1 \mathrm{H},=\mathrm{C}^{1} \mathrm{H}_{2}\right), 5.28\left(\mathrm{~d}, J=17.3 \mathrm{~Hz}, 1 \mathrm{H},=\mathrm{C}^{1} \mathrm{H}_{2}\right)$, 5.82$5.90\left(\mathrm{~m}, 1 \mathrm{H},-\mathrm{C}^{2} \mathrm{H}=\right) .{ }^{19} \mathrm{~F}$ NMR spectrum, $\delta$, ppm: -75.19 (t, $\left.J=8.4 \mathrm{~Hz}, 3 \mathrm{~F}, \mathrm{C}^{5} \mathrm{~F}_{3}\right)$. IR spectrum, $\mathrm{cm}^{-1}:$ 3092, 2940, $2868\left(v_{\mathrm{C}-\mathrm{H}}\right), 1651\left(v_{\mathrm{C}=\mathrm{C}}\right), 1277\left(v_{\mathrm{C}-\mathrm{O}-\mathrm{C}}\right), 1154\left(v_{\mathrm{CF}}\right)$.

3- [2,2,2-Trifluoro-1-(trifluoromethyl)ethoxy] propene (Ib) was obtained as a colorless liquid $56.6 \mathrm{~g}$ (85\%). ${ }^{1} \mathrm{H}$ NMR spectrum, $\delta$, ppm: 4.05-4.12 (m, 1H, $\mathrm{C}^{4} \mathrm{H}-$ ), 4.30 (d, J=5.8 Hz, $2 \mathrm{H}, \mathrm{O}-\mathrm{C}^{3} \mathrm{H}_{2}$ ), 5.34-5.38 (m, $\left.2 \mathrm{H},=\mathrm{C}^{1} \mathrm{H}_{2}\right)$, 5.83-5.91 (m, $\left.1 \mathrm{H},-\mathrm{C}^{2} \mathrm{H}=\right)$. ${ }^{19} \mathrm{~F} \quad \mathrm{NMR}$ spectrum, $\delta$, ppm: -74.83 (d, $\left.J=6.8 \mathrm{~Hz}, 6 \mathrm{~F},\left(\mathrm{CF}_{3}\right)_{2} \mathrm{C}^{4} \mathrm{H}-\right)$. IR spectrum, $\mathrm{cm}^{-1}$ : 3093, 2937, $2892\left(v_{\mathrm{C}-\mathrm{H}}\right), 1650\left(v_{\mathrm{C}=\mathrm{C}}\right)$, 1287 ( $\left.v_{\mathrm{C}-\mathrm{O}-\mathrm{C}}\right), 1190,1132\left(\mathrm{v}_{\mathrm{CF}}\right)$.

3-(2,2,3,3,4,4,5,5,5-Nonafluoropentoxy)propene (Ic) was obtained as a colorless liquid $102.9 \mathrm{~g}$ (71\%).

3-(2,2,3,3-Tetrafluoropropoxy)propene (Id) was obtained as a colorless liquid $65.9 \mathrm{~g}$ (72\%); b.p. $110^{\circ} \mathrm{C}$. ${ }^{1} \mathrm{H}$ NMR spectrum, $\delta$, ppm: $3.77(\mathrm{t}, J=11.9 \mathrm{~Hz}, 2 \mathrm{H}$, $\mathrm{C}^{5} \mathrm{~F}_{2}-\mathrm{C}^{4} \mathrm{H}_{2}$ ), 4.06 (d, $J=5.7 \mathrm{~Hz}, 2 \mathrm{H}, \mathrm{O}-\mathrm{C}^{3} \mathrm{H}_{2}$ ), 5.22 (d, $\left.J=10.5 \mathrm{~Hz}, 1 \mathrm{H},=\mathrm{C}^{1} \mathrm{H}_{2}\right), 5.26(\mathrm{~d}, J=17.4 \mathrm{~Hz}, 1 \mathrm{H}$, $\left.=\mathrm{C}^{1} \mathrm{H}_{2}\right), 5.81-5.88\left(\mathrm{M}, 1 \mathrm{H},-\mathrm{C}^{2} \mathrm{H}=\right)$, $5.90\left(\mathrm{t} . t,{ }^{3} J_{\mathrm{H}-\mathrm{F}}=53.3\right.$ $\left.\mathrm{Hz},{ }^{2} J_{\mathrm{H}-\mathrm{F}}=5.3 \mathrm{~Hz}, 1 \mathrm{H}, \mathrm{HC}{ }^{6} \mathrm{~F}_{2}\right) .{ }^{19} \mathrm{~F}$ NMR spectrum, $\delta$, ppm: -141.11 (d, $J=54.4 \mathrm{~Hz}, 2 \mathrm{~F},\left(\mathrm{HC}^{6} \mathrm{~F}_{2}-\right), 126.45$ (s, 2F, $\left.-\mathrm{C}^{5} \mathrm{~F}_{2}-\right)$. IR spectrum, $\mathrm{cm}^{-1}: 3091,2928,2876\left(v_{\mathrm{C}-\mathrm{H}}\right)$, $1651\left(v_{\mathrm{C}=\mathrm{C}}\right), 1204\left(v_{\mathrm{C}-\mathrm{O}-\mathrm{C}}\right), 1099\left(v_{\mathrm{CF}}\right)$.

3-(2,2,3,3,4,4,5,5-Octafluoropentoxy)propene (Ie) was obtained as a colorless liquid $53.9 \mathrm{~g}$ (66\%); b.p. 152-154 ${ }^{\circ} \mathrm{C} .{ }^{1} \mathrm{H}$ NMR spectrum, $\delta$, ppm: $3.89(\mathrm{t}, J=14 \mathrm{~Hz}$, $2 \mathrm{H},-\mathrm{C}^{5} \mathrm{~F}_{2}-\mathrm{C}^{4} \mathrm{H}_{2}-$ ), 4.10 (d, J=5.7 Hz, 2H, O-C ${ }^{3} \mathrm{H}_{2}$ ), 5.23 (d, $\left.J=10.7 \mathrm{~Hz}, 1 \mathrm{H},=\mathrm{C}^{1} \mathrm{H}_{2}\right), 5.28(\mathrm{~d}, J=17.2 \mathrm{~Hz}, 1 \mathrm{H}$, $\left.=\mathrm{C}^{1} \mathrm{H}_{2}\right), 5.82-5.92\left(\mathrm{~m}, 1 \mathrm{H},-\mathrm{C}^{2} \mathrm{H}=\right), 6.03\left(\mathrm{t} . t,{ }^{3} J_{\mathrm{H}-\mathrm{F}}=51.9\right.$ $\left.\mathrm{Hz}, \quad{ }^{2} J_{\mathrm{H}-\mathrm{F}}=5.7 \mathrm{~Hz}, 1 \mathrm{H}, \mathrm{HC}^{8} \mathrm{~F}_{2}\right) .{ }^{1} \mathrm{H}$ NMR spectrum, $\delta$, ppm: -138.44 (d, $J=52 \mathrm{~Hz}, 2 \mathrm{~F}, \mathrm{HC}^{8} \mathrm{~F}_{2}$ ) $)-131.41$ (s, 2F, $\mathrm{C}^{7} \mathrm{~F}_{2}-$ ), -126.7 (t, J=8.5 Hz, 2F, $-\mathrm{C}^{6} \mathrm{~F}_{2}-$ ), -120.75 (s, 2F, $\left.\mathrm{C}^{5} \mathrm{~F}_{2}-\right)$. IR spectrum, $\mathrm{cm}^{-1}: 3091,2945,2872\left(v_{\mathrm{C}-\mathrm{H}}\right)$, $1651\left(v_{\mathrm{C}=\mathrm{C}}\right), 1288\left(v_{\mathrm{C}-\mathrm{O}-\mathrm{C}}\right), 1165,1123\left(v_{\mathrm{CF}}\right)$.

3-(2,2,3,3,4,4,5,5,6,6,7,7-Dodecafluoroheptoxy) propene (If) was obtained as a colorless liquid $84.9 \mathrm{~g}$ (76\%).

\subsubsection{General procedure for preparing 3- polyfluoroalkoxypropenes (method B)}

Fluoroalkanol, 5-10 ml of 1.4-dioxane and 1.5-3.9 (0.05$0.012 \mathrm{~mol}$ ) of tetrabutylammonium bromide (TBAB) in 
water (10-15 ml) was added to a solution of 7-30 g (0.12-0.55 mol) of potassium hydroxide dissolved in water $(16-68 \mathrm{ml})$. The mixture was heated to $50-60^{\circ} \mathrm{C}$ and kept at this temperature for one hour. Allyl bromide was then added dropwise over 30-60 minutes, preventing the formation of the intense reflux in a condenser. The reaction mixture was kept with constant stirring for 1-8 hours $\left(50-90^{\circ} \mathrm{C}\right)$. The organic layer was separated, washed with water until neutral according to a universal indicator. The remaining allyl bromide was removed by treatment with $\mathrm{Na}_{2} \mathrm{SO}_{3}\left(\mathrm{Na}_{2} \mathrm{SO}_{3} \cdot 7 \mathrm{H}_{2} \mathrm{O}\right) 15 \mathrm{~g}$ dissolved in water $(100 \mathrm{ml})$, and the mixture was stirred for $4 \mathrm{hr}$ at $60-90^{\circ} \mathrm{C}$. The organic phase was then separated, washed with water, dried with anhydrous $\mathrm{MgSO}_{4}\left(\mathrm{Na}_{2} \mathrm{SO}_{4}\right)$ and filtered. The target products were purified by azeotropic distillation with water to give the corresponding 3polyfluoroalkoxypropenes in $80-94 \%$ yields. The reaction conditions are presented in Table 2.

3-(2,2,2-Trifluoroethoxy)propene (Ia) was obtained as a colorless liquid $44.6 \mathrm{~g}(80 \%)$; b.p. $75^{\circ} \mathrm{C}$.

3-(2,2,3,3,4,4,5,5,5-Nonafluoropentoxy)propene (Ic) was obtained as a colorless liquid $51 \mathrm{~g}(88 \%) .{ }^{1} \mathrm{H}$ NMR spectrum, $\delta$, ppm: 4.07-4.12 (4H, $\left.-\mathrm{C}^{4} \mathrm{H}_{2}-\mathrm{O}-\mathrm{C}^{3} \mathrm{H}_{2}-\right), 5.18$ (d, $\left.J=11.8 \mathrm{~Hz}, 1 \mathrm{H},=\mathrm{C}^{1} \mathrm{H}_{2}\right), 5.26(\mathrm{~d}, J=17.3 \mathrm{~Hz}, 1 \mathrm{H}$, $\left.=\mathrm{C}^{1} \mathrm{H}_{2}\right)$, 5.82-5.90 $\left(\mathrm{m}, 1 \mathrm{H},-\mathrm{C}^{2} \mathrm{H}=\right) .{ }^{19} \mathrm{~F}$ NMR spectrum, $\delta$, ppm: $-126,45$ (t, $J=12.9 \mathrm{~Hz}, 2 \mathrm{~F},-\mathrm{C}^{5} \mathrm{~F}_{2}-$ ), -124.15 (s, $\left.2 \mathrm{~F},-\mathrm{C}^{6} \mathrm{~F}_{2-}\right)$, -119.48-119.37 (m, 2F, $\left.-\mathrm{C}^{7} \mathrm{~F}_{2}-\right)$, -81.07 (t, $\left.J=8.5 \mathrm{~Hz}, 3 \mathrm{~F}, \mathrm{C}^{8} \mathrm{~F}_{3}-\right)$. IR spectrum, $\mathrm{cm}^{-1}$ : 3092, 2934, $2871\left(v_{\mathrm{C}-\mathrm{H}}\right), 1651\left(v_{\mathrm{C}=\mathrm{C}}\right), 1225\left(v_{\mathrm{C}-\mathrm{O}-\mathrm{C}}\right), 1132\left(v_{\mathrm{CF}}\right)$.

3-(2,2,3,3-Tetrafluoropropoxy)propene (Id) was obtained as a colorless liquid $46.6 \mathrm{~g}(90 \%)$; b.p. $110^{\circ} \mathrm{C}$.

3-(2,2,3,3,4,4,5,5-Octafluoropentoxy)propene was obtained as a colorless liquid $76.9 \mathrm{~g}(94 \%)$.

3-(2,2,3,3,4,4,5,5,6,6,7,7-Dodecafluoroheptoxy) propene (If) was obtained as a colorless liquid $69.2 \mathrm{~g}$ (93\%). ${ }^{1} \mathrm{H}$ NMR spectrum, $\delta$, ppm: 4.07-4.13 (4H, $\mathrm{C}^{4} \mathrm{H}_{2}-\mathrm{O}-\mathrm{C}^{3} \mathrm{H}_{2}-$ ), 5.20 (d, J=10.4 Hz, $\left.1 \mathrm{H},=\mathrm{C}^{1} \mathrm{H}_{2}\right), 5.27$ (d, $\left.J=17.1 \mathrm{~Hz}, 1 \mathrm{H},=\mathrm{C}^{1} \mathrm{H}_{2}\right)$, 5.84-5.91 (m, $1 \mathrm{H},-\mathrm{C}^{2} \mathrm{H}=$ ), 7.11 (t.t, ${ }^{3} J_{\mathrm{H}-\mathrm{F}}=49.9 \mathrm{~Hz},{ }^{2} J_{\mathrm{H}-\mathrm{F}}=5.3 \mathrm{~Hz}, 1 \mathrm{H}, \mathrm{HC}^{10} \mathrm{~F}_{2}$ ). ${ }^{19} \mathrm{~F}$ NMR spectrum, $\delta$, ppm: -138.61 (d, $J=49.9 \mathrm{~Hz}, 2 \mathrm{~F}$, $\mathrm{HC}^{10} \mathrm{~F}_{2}-$ ), -129.2 (s, 2F, $-\mathrm{C}^{9} \mathrm{~F}_{2}-$ ), -123.18 (s, 4F, - $\mathrm{C}^{8} \mathrm{~F}_{2-}$ $\mathrm{C}^{7} \mathrm{~F}_{2}-$ ), -122.26 (s, 2F, - $\left.\mathrm{C}^{6} \mathrm{~F}_{2}-\right)$, -119.10-118.99 (m, 2F, $\left.\mathrm{C}^{5} \mathrm{~F}_{2}-\right)$. IR spectrum, $\mathrm{cm}^{-1}:$ 3092, 2935, $2875\left(v_{\mathrm{C}-\mathrm{H}}\right)$, $1652\left(v_{\mathrm{C}=\mathrm{C}}\right), 1264\left(v_{\mathrm{C}-\mathrm{O}-\mathrm{C}}\right), 1193,1138\left(v_{\mathrm{CF}}\right)$.

3-(2,2,3,3,4,4,5,5,6,6,7,7,8,8,9,9-Hexadecafluorononaloxy)propene (Ig) was obtained as a colorless liquid $39 \mathrm{~g}(90 \%) .{ }^{1} \mathrm{H}$ NMR spectrum, $\delta$, ppm: 4.04-4.11 (4H, $\mathrm{C}^{4} \mathrm{H}_{2}-\mathrm{O}-\mathrm{C}^{3} \mathrm{H}_{2}-$ ), 5.18 (d, J=10.6 Hz, $1 \mathrm{H},=\mathrm{C}^{1} \mathrm{H}_{2}$ ), 5.26 (d, $\left.J=17.2 \mathrm{~Hz}, 1 \mathrm{H},=\mathrm{C}^{1} \mathrm{H}_{2}\right), 5.82-5.90\left(\mathrm{~m}, 1 \mathrm{H},-\mathrm{C}^{2} \mathrm{H}=\right.$ ), 7.09 (t.t, ${ }^{3} J_{\mathrm{H}-\mathrm{F}}=50.1 \mathrm{~Hz},{ }^{2} J_{\mathrm{H}-\mathrm{F}}=4.8 \mathrm{~Hz}, 1 \mathrm{H}, \mathrm{HC}^{12} \mathrm{~F}_{2}$ ) ${ }^{19} \mathrm{~F}$ NMR spectrum, $\delta$, ppm: -138.82 (d, $J=50.6 \mathrm{~Hz}, 2 \mathrm{~F}$, $\mathrm{HC}^{12} \mathrm{~F}_{2}-$ ), -129.23 (s, 2F, $-\mathrm{C}^{11} \mathrm{~F}_{2}$ ), -123.26 (s, 4F, $\mathrm{C}^{10} \mathrm{~F}_{2}-\mathrm{C}^{9} \mathrm{~F}_{2}-$ ), -122.18 (s, 6F, $-\mathrm{C}^{8} \mathrm{~F}_{2}-\mathrm{C}^{7} \mathrm{~F}_{2}-\mathrm{C}^{6} \mathrm{~F}_{2}-$ ), 119.24 (s, 2F, $-\mathrm{C}^{5} \mathrm{~F}_{2^{-}}$). IR spectrum, $\mathrm{cm}^{-1}: 3093,2873$ $\left(v_{\mathrm{C}-\mathrm{H}}\right), \quad 1652 \quad\left(v_{\mathrm{C}=\mathrm{C}}\right), \quad 1204 \quad\left(v_{\mathrm{C}-\mathrm{O}-\mathrm{C}}\right), 1131\left(v_{\mathrm{CF}}\right)$.
Table 2. 3-Polyfluoroalkoxypropenes (allyl fluoroalkyl ethers) synthesis by method B

\begin{tabular}{|c|c|c|c|c|c|c|}
\hline $\begin{array}{c}\text { Allyl } \\
\text { ether }\end{array}$ & $\begin{array}{c}\text { Allyl } \\
\text { bromide, } \\
\mathbf{g}(\mathbf{m o l})\end{array}$ & $\begin{array}{c}\text { Fluoro- } \\
\text { alkanol, } \\
\mathbf{g}(\mathbf{m o l})\end{array}$ & $\begin{array}{c}\text { TBAB, } \\
\mathbf{g} \text { (mol) }\end{array}$ & $\begin{array}{c}\text { Allyl } \\
\text { bromide: } \\
\text { fluoro- } \\
\text { alkanol }\end{array}$ & $\begin{array}{c}\boldsymbol{\tau}, \\
\mathbf{h r}\end{array}$ & $\begin{array}{c}\mathbf{T}, \\
{ }^{\circ} \mathbf{C}\end{array}$ \\
\hline Ia & $48.5(0.4)$ & $\begin{array}{c}33.4 \\
(0.34)\end{array}$ & $\begin{array}{c}3.9 \\
(0.012)\end{array}$ & $1.2: 1$ & 1 & $\begin{array}{c}50- \\
60\end{array}$ \\
\hline Ic & $29(0.24)$ & $50(0.2)$ & $\begin{array}{c}1.4 \\
(0.004)\end{array}$ & $1.2: 1$ & 5 & $\begin{array}{c}60- \\
90\end{array}$ \\
\hline Id & $39.9(0.33)$ & $\begin{array}{c}39.6 \\
(0.3)\end{array}$ & $\begin{array}{c}2.9 \\
(0.009)\end{array}$ & $1.1: 1$ & 4 & $\begin{array}{c}60- \\
90\end{array}$ \\
\hline Ie & $39.3(0.33)$ & $\begin{array}{c}69.6 \\
(0.3)\end{array}$ & $\begin{array}{c}2.9 \\
(0.009)\end{array}$ & $1.1: 1$ & 5 & $\begin{array}{c}60- \\
90\end{array}$ \\
\hline If & $29(0.24)$ & $\begin{array}{c}66.5 \\
(0.2)\end{array}$ & $\begin{array}{c}3.2 \\
(0.01)\end{array}$ & $1.2: 1$ & 14 & $\begin{array}{c}65- \\
90\end{array}$ \\
\hline Ig & $13.3(0.11)$ & $\begin{array}{c}39.6 \\
(0.09)\end{array}$ & $\begin{array}{c}1.5 \\
(0.005)\end{array}$ & $1.2: 1$ & 8 & $\begin{array}{c}70- \\
90\end{array}$ \\
\hline
\end{tabular}

\section{Results and Discussion}

There are several options for the reaction of polyfluoroalkanols with allyl halides, which differ the presence of a solvent, the method of generating alcoholates, and the use of PTC. In the case of fluoroalkanols the classical Williamson ether reaction (acetone, $\mathrm{K}_{2} \mathrm{CO}_{3}$, reflux) also leads to the formation of target ethers (yield 52 - 87\%) [19].

Organic solvents have been often used for the synthesis of polyfluoroalkoxypropenes as a reaction medium. Stewart obtained 2,2,2-trifluoroethanol and $1 \mathrm{H}, 1 \mathrm{H}$-heptafluorobutanol allyl ethers in $52-67 \%$ yields by heating the corresponding alcohols and allyl halides (chloride, bromide) in diglyme, diethyl ether, and acetone in the presence of sodium or $\mathrm{K}_{2} \mathrm{CO}_{3}$ [12]. The use of acetonitrile allowed Il'yin with the co-workers [7] to obtain $\alpha, \alpha, \omega$-trihydroperfluoropentanol allyl ether (allyl bromide, $\mathrm{KOH}$ ) in 95\% yield. Maciejewski with the co-workers [20] synthesized $\alpha, \alpha, \omega$ trihydroperfluoropropanol and $\alpha, \alpha, \omega$ trihydroperfluoropentanol allyl ethers by heating the corresponding fluoroalkanols with allyl chloride in benzene in the presence of sodium hydroxide and catalytic amounts of 4-dimethylaminopiperidine in 78$79 \%$ yields. Rakhimova obtained $\alpha, \alpha, \omega-$ trihydroperfluoropentanol and $\alpha, \alpha, \omega$ trihydroperfluoroheptanol allyl ethers in 54-84\% yields by the reaction of allyl iodide (allyl bromide) with alcoholates in 1,4-dioxane [21]. Aprotic polar solvents such as dimethylformamide and diglyme are effective when it is necessary to obtain allyl ether of a fully fluorinated alcohol [13, 15, 22].

According to the publications of recent decades, it is more preferable to carry out the interaction in question in aqueous medium. The intensification of mass transfer is solved by intensive stirring [23], as well as the use of PTC [16, 17]. Boutevin with the co-workers [24] used PTC for the synthesis of polyfluoroalkoxypropenes for the first time. It was shown that the interaction of various structure fluoroalkanols with allyl chloride in a 50\% sodium hydroxide solution in the presence of quaternary ammonium salts (TBAHS) leads to the target products in yield to $95 \%$. However, the yield was not more than $50 \%$ with a continuous treatment $(6 \mathrm{~h})$ in the case of 2,2,2- 
trifluoroethanol. Subsequently, this method was used by other researchers in a number of studies for the synthesis of allyl ethers of predominantly lower homologues of fluoroalkanols - 2,2,2-trifluoroethanol and 1,1,3trihydroperfluoropropanol [17, 23, 25]. The carrying out of the process in question is more preferable in aqueous medium from the point of view of safety and manufacturability.

We carried out a series of experiments to obtain polyfluoroalkoxypropenes using different chain length fluoroalkanols to determine the need of application PTC (Table 3). The allyl ethers synthesis was carried out using an aqueous solution of $\mathrm{KOH}$ (25-30\%) in two versions. In the first variant, 1,4-dioxane was added to the reaction mixture in an amount of 5-15 vol.\% (method A) to improve mass transfer. In the second variant, in addition to 1,4-dioxane PTC (tetrabutylammonium bromide) was added to the reaction mixture in an amount of 3-5 mol\% (method B). The reaction mixtures were kept with constant stirring, heating for a certain time, and monitoring by GLC.

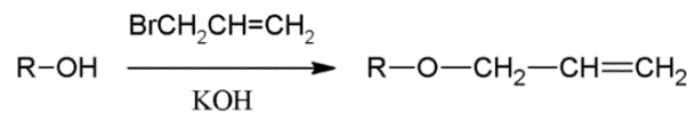

Ia-g,

$\mathrm{R}=\mathrm{CF}_{3} \mathrm{CH}_{2}(\mathbf{a}),\left(\mathrm{CF}_{3}\right)_{2} \mathrm{CH}(\mathbf{b}), \mathrm{CF}_{3}\left(\mathrm{CF}_{2}\right)_{3} \mathrm{CH}_{2}(\mathbf{c})$, $\mathrm{HCF}_{2} \mathrm{CF}_{2} \mathrm{CH}_{2}$ (d), $\mathrm{H}_{(}\left(\mathrm{CF}_{2} \mathrm{CF}_{2}\right)_{2} \mathrm{CH}_{2}(\mathbf{e}), \mathrm{H}_{(}\left(\mathrm{CF}_{2} \mathrm{CF}_{2}\right)_{3} \mathrm{CH}_{2}$ (f), $\mathrm{H}\left(\mathrm{CF}_{2} \mathrm{CF}_{2}\right)_{4} \mathrm{CH}_{2}(\mathbf{g})$

\section{Scheme 1}

During gas chromatographic analysis of the starting materials and reaction products, we calculated the retention indices (Kovacs indices) of some polyfluoroalkoxypropenes by linear interpolation of the corrected retention parameters $\left(t_{R}^{\prime}\right)$ [26]. We used retention times as the primary parameters $\left(t_{R}\right)$. Fluoroalkanols were applied as standard compounds. The calculation was carried out according to the following formula:

$$
I_{x}=100\left[\frac{\lg t_{R(x)}^{\prime}-\lg t_{R(n)}^{\prime}}{\lg t_{R(n+1)}^{\prime}-\lg t_{R(n)}^{\prime}}+n\right]
$$

subject to the conditions:

$$
t_{R(n)}^{\prime} \leq t_{R(x)}^{\prime} \leq t_{R(n+1)}^{\prime}
$$

The content of the starting alcohols was $1-4 \%$ in the reaction mass at the end of the process in the case of lower homologues (a, b, d) when carrying out the reaction according to method A (fig. 1-3). However, the content of $1 \mathrm{H}, 1 \mathrm{H}$-nonafluoropentanol (c) was about $20 \%$. It did not decrease with increasing treatment time (fig. 4).

The complete conversion was not observed in the reactions with other fluoroalkanols having a chain length of 5 carbon atoms and more (e, f). The content of the starting alcohols in the reaction mass remained significant (about 15-25\%) after increasing the duration of treatment (fig. 5.6). The incomplete conversion of polyfluoroalkanols containing 5 or more carbon atoms in the chain is apparently associated with their high density and lipophilicity compared to lower homologs [9]. The use of PTC was an acceptable solution to this problem.

The second series of experiments (method B) was carried out with the addition of tetrabutylammonium bromide. It is one of the most common PTC [27]. The complete conversion of fluoroalkanols (a, c, d, and g) was achieved using PTC in the amount of 3-5 mol\% in relation to fluoroalkanols (fig. 1,3,4). The conversion of other fluoroalkanols (e, f, and g) was significantly increased using the above conditions (e, $\mathrm{f}$ and g) (fig. 2,5,6).

Quaternary bases are known to be sensitive to heat, especially in the presence of base. Tetrabutylammonium salt decomposes to tributylamine by $52 \%$ at $60{ }^{\circ} \mathrm{C}$ and by $97 \%$ at $100{ }^{\circ} \mathrm{C}$ in the presence of conc. $\mathrm{NaOH}$ in 7 days [27].

$$
\begin{aligned}
\mathrm{R}_{4} \mathrm{~N}^{+} \mathrm{A}^{-}+\mathrm{OH}^{-} & \rightarrow \mathrm{R}_{4} \mathrm{~N}^{+} \mathrm{OH}^{-}+\mathrm{A}^{-} \\
\mathrm{R}_{4} \mathrm{~N}^{+} \mathrm{OH}^{-} & \rightarrow \mathrm{R}_{3} \mathrm{~N}+\mathrm{ROH}
\end{aligned}
$$

Scheme 2

In the process of synthesis of allyl ethers (Ic, If, Ig), we found (GLC method) that a noticeable decomposition of tetrabutylammonium bromide occurred almost at the end of the main reaction (after 2-3 hours after a start of treatment). The products of decomposition were identified by comparing the retention times of individual

\begin{tabular}{|c|c|c|c|c|c|c|c|c|}
\hline \multirow{2}{*}{$\begin{array}{l}\mathrm{R}-\mathrm{O}-\mathrm{CH}_{2-}- \\
\mathrm{CH}=\mathrm{CH}_{2}, \\
\mathbf{R}=\end{array}$} & \multirow{2}{*}{ Method } & \multicolumn{2}{|c|}{$\begin{array}{c}\text { Retention time, } \\
\text { sec }\end{array}$} & \multirow{2}{*}{$I$} & \multirow{2}{*}{$\begin{array}{l}\text { Allyl ether, } \\
\text { mass. \% }\end{array}$} & \multirow{2}{*}{$\begin{array}{c}\text { Fluoroalkanol, } \\
\text { mass. \% }\end{array}$} & \multirow{2}{*}{$\begin{array}{c}\text { Raw } \\
\text { yield, } \\
\%\end{array}$} & \multirow{2}{*}{$\underset{\%}{\text { Yield, }}$} \\
\hline & & $\begin{array}{l}\text { Allyl } \\
\text { ether }\end{array}$ & Fluoroalkanol & & & & & \\
\hline \multirow{2}{*}{$\begin{array}{l}\mathrm{CF}_{3} \mathrm{CH}_{2}- \\
\text { (Ia) }\end{array}$} & $\mathrm{A}$ & \multirow{2}{*}{140.3} & \multirow{2}{*}{96.2} & \multirow{2}{*}{269.4} & 88.9 & 2.6 & 87 & 78 \\
\hline & $\mathrm{B}$ & & & & 85.5 & 0 & 94 & 80 \\
\hline $\begin{array}{l}\left(\mathrm{CF}_{3}\right)_{2} \mathrm{CH}- \\
\text { (Ib) }\end{array}$ & $\mathrm{A}$ & 143.6 & 97.5 & 271.4 & 93.8 & 0.5 & 91 & 85 \\
\hline \multirow{2}{*}{$\begin{array}{l}\mathrm{CF}_{3}\left(\mathrm{CF}_{2}\right)_{3} \mathrm{CH}_{2}- \\
\text { (Ic) }\end{array}$} & $\mathrm{A}$ & \multirow{2}{*}{213.1} & \multirow{2}{*}{179.5} & \multirow{2}{*}{550} & 78 & 19.3 & 92 & 71 \\
\hline & $\mathrm{B}$ & & & & 97.9 & 0 & 90 & 88 \\
\hline \multirow{2}{*}{$\begin{array}{l}\mathrm{HCF}_{2} \mathrm{CF}_{2} \mathrm{CH}_{2}- \\
\text { (Id) }\end{array}$} & $\mathrm{A}$ & \multirow{2}{*}{217.8} & \multirow{2}{*}{171.3} & \multirow{2}{*}{352.4} & 91.3 & 4.3 & 79 & 72 \\
\hline & $\mathrm{B}$ & & & & 94.3 & 0 & 96 & 90 \\
\hline \multirow{2}{*}{$\begin{array}{l}\mathrm{H}\left(\mathrm{CF}_{2} \mathrm{CF}_{2}\right)_{2} \mathrm{CH}_{2}- \\
\text { (Ie) }\end{array}$} & $\mathrm{A}$ & \multirow{2}{*}{301.6} & \multirow{2}{*}{260.7} & \multirow{2}{*}{560.8} & 78.4 & 18.7 & 84 & 66 \\
\hline & $\mathrm{B}$ & & & & 97 & 1.5 & 97 & 94 \\
\hline \multirow{2}{*}{$\begin{array}{l}\mathrm{H}\left(\mathrm{CF}_{2} \mathrm{CF}_{2}\right)_{3} \mathrm{CH}_{2}- \\
\text { (If) }\end{array}$} & $\mathrm{A}$ & \multirow{2}{*}{362.4} & \multirow{2}{*}{331.2} & \multirow{2}{*}{750} & 70.8 & 23.6 & 97 & 76 \\
\hline & $\mathrm{B}$ & & & & 96.9 & 2.4 & 96 & 93 \\
\hline $\begin{array}{l}\mathrm{H}\left(\mathrm{CF}_{2} \mathrm{CF}_{2}\right)_{4} \mathrm{CH}_{2-} \\
\text { (Ig) }\end{array}$ & $\mathrm{B}$ & 416.6 & 388.6 & - & 95.6 & 0.56 & 94 & 90 \\
\hline
\end{tabular}
substances (tributylamine and $n$-butyl alcohol) (GLC method).

Table 3. GLC data and yields of polyfluoroalkoxypropenes

${ }^{\mathrm{A}} \mathrm{KOH}(25-30 \%), 90{ }^{\circ} \mathrm{C} ;{ }^{\mathrm{B}} \mathrm{KOH}(25-30 \%), 90^{\circ} \mathrm{C}, \mathrm{TBAB}$ 


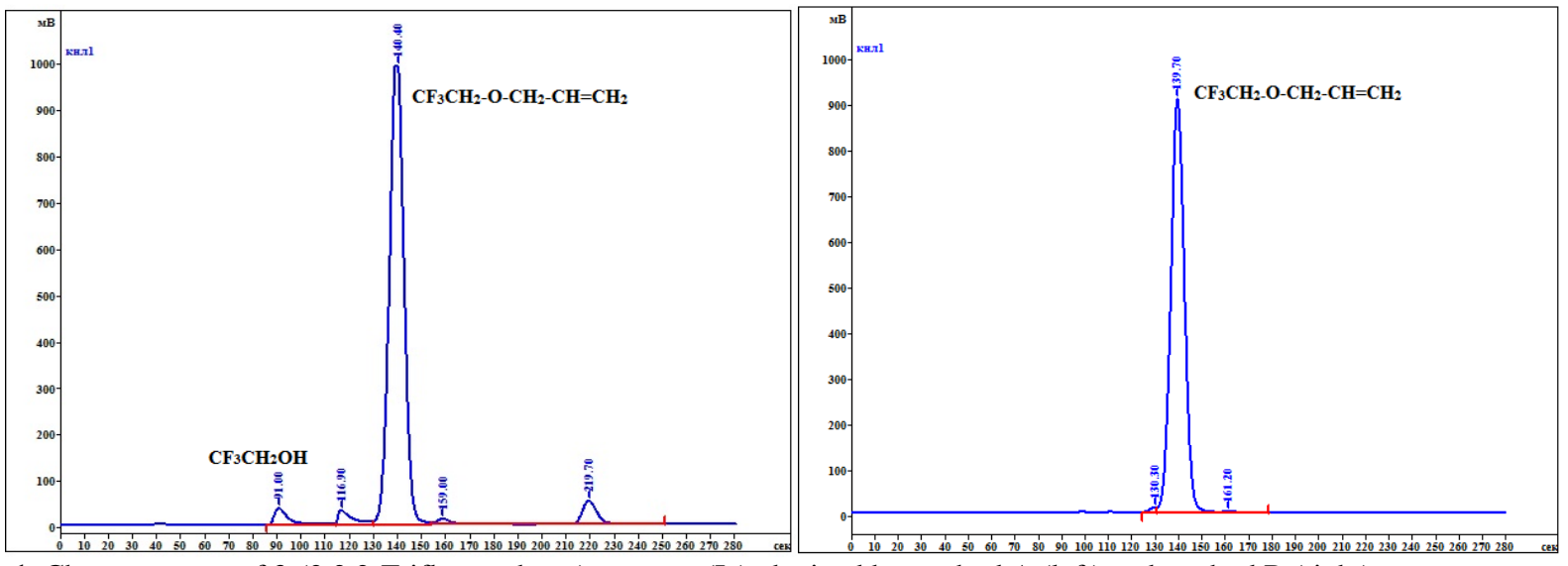

Fig. 1. Chromatogram of 3-(2,2,2-Trifluoroethoxy) propene (Ia) obtained by method A (left) and method B (right).
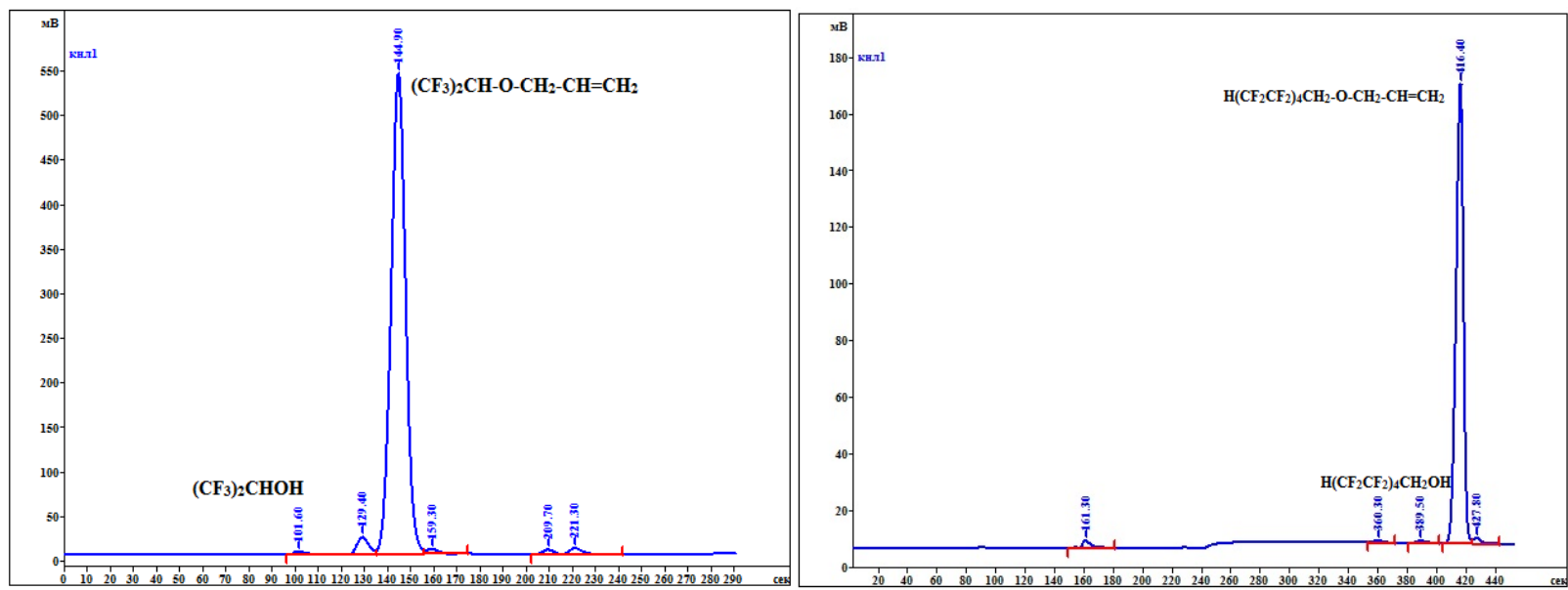

Fig. 2. Chromatogram of 3- [2,2,2-Trifluoro-1-(trifluoromethyl) ethoxy] propene (Ib) obtained by method A (left) and 3(2,2,3,3,4,4,5,5,6,6,7,7,8,8,9,9-Hexadecafluoro-nonaloxy)propene (Ig) obtained by method B (right).
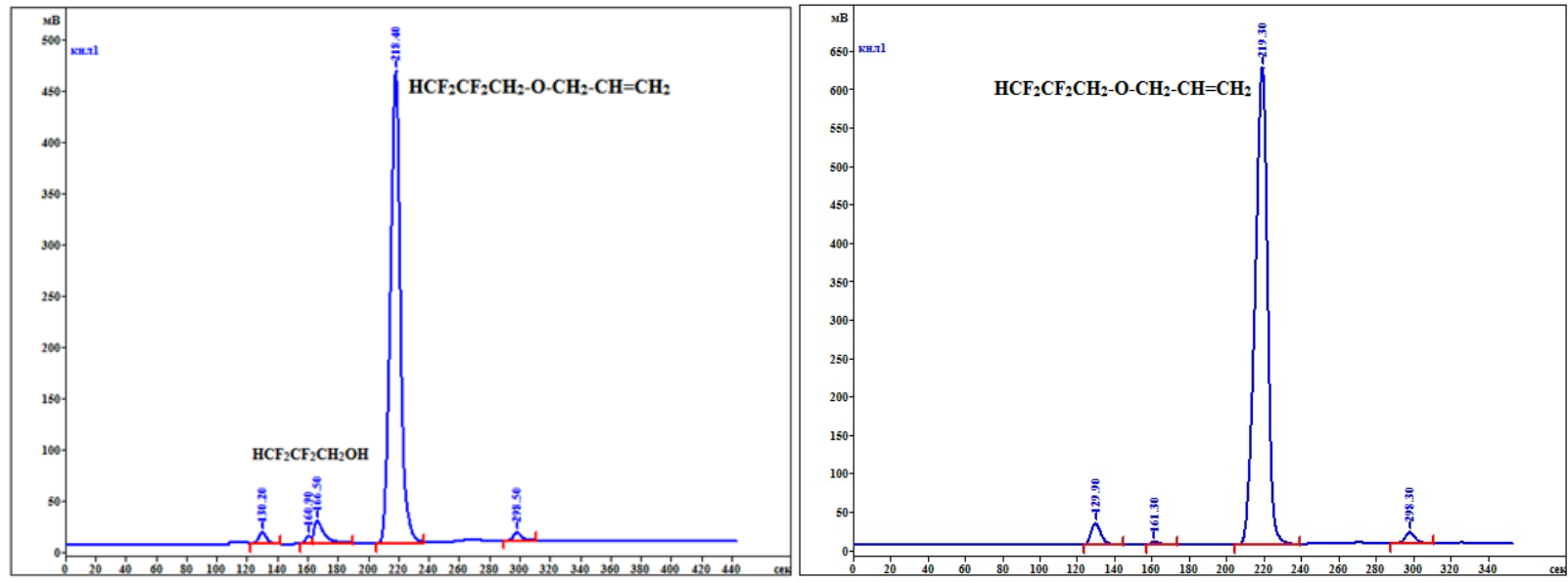

Fig. 3. Chromatogram of 3-(2,2,3,3-Tetrafluoropropoxy) propene (Id) obtained by method A (left) and method B(right). 

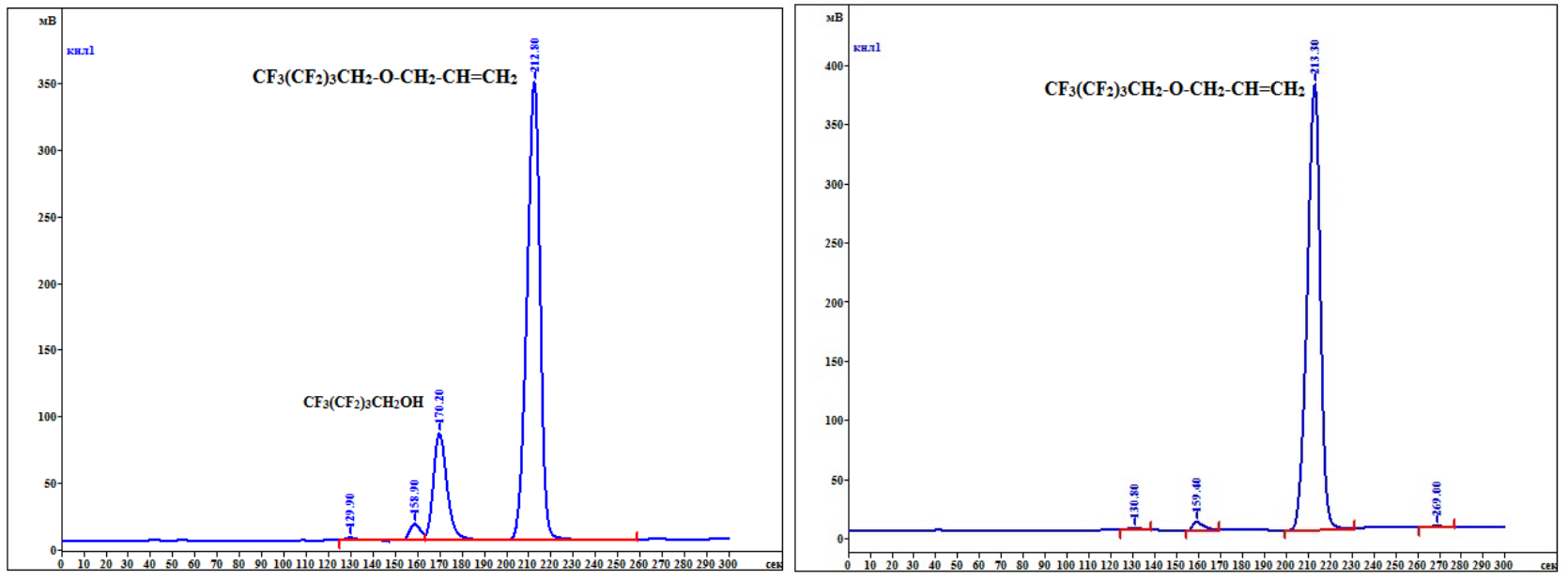

Fig. 4. Chromatogram of 3-(2,2,3,3,4,4,5,5,5-Nonafluoropentoxy) propene (Ic) obtained by method A (left) and method B (right).

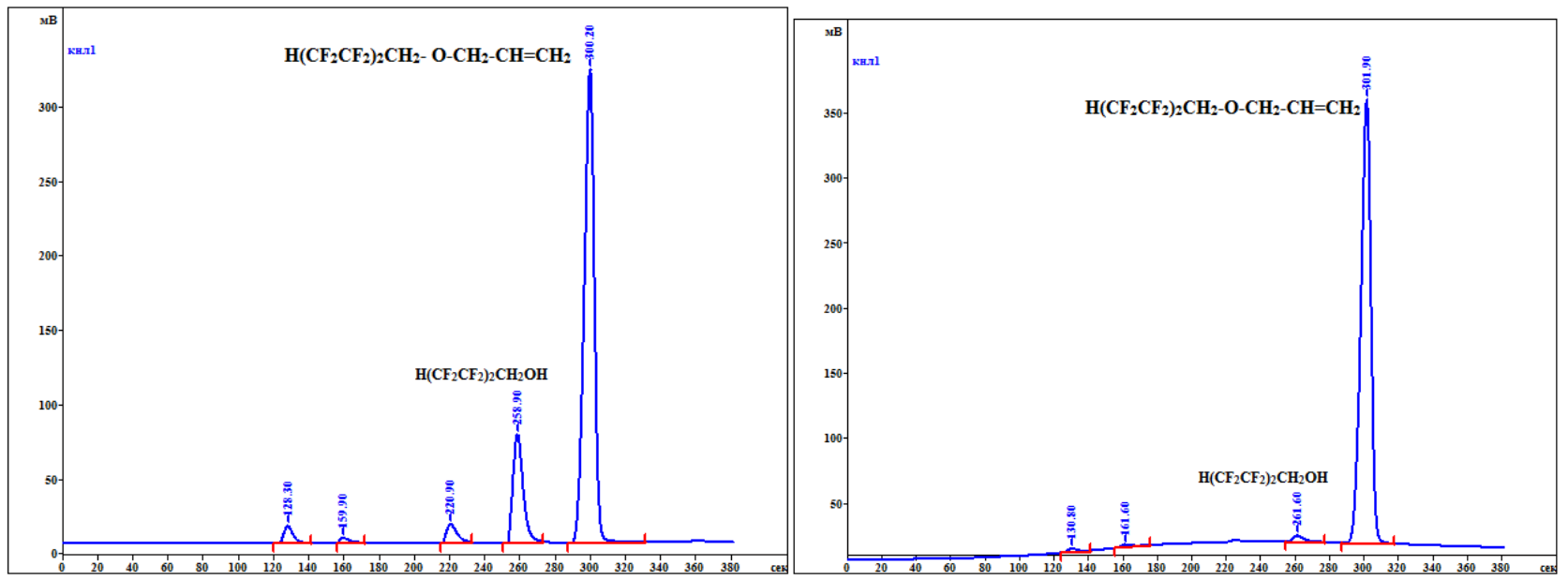

Fig. 5. Chromatogram of 3-(2,2,3,3,4,4,5,5-Octafluoropentoxy) propene (Ie) obtained by method A (left) and method B (right).
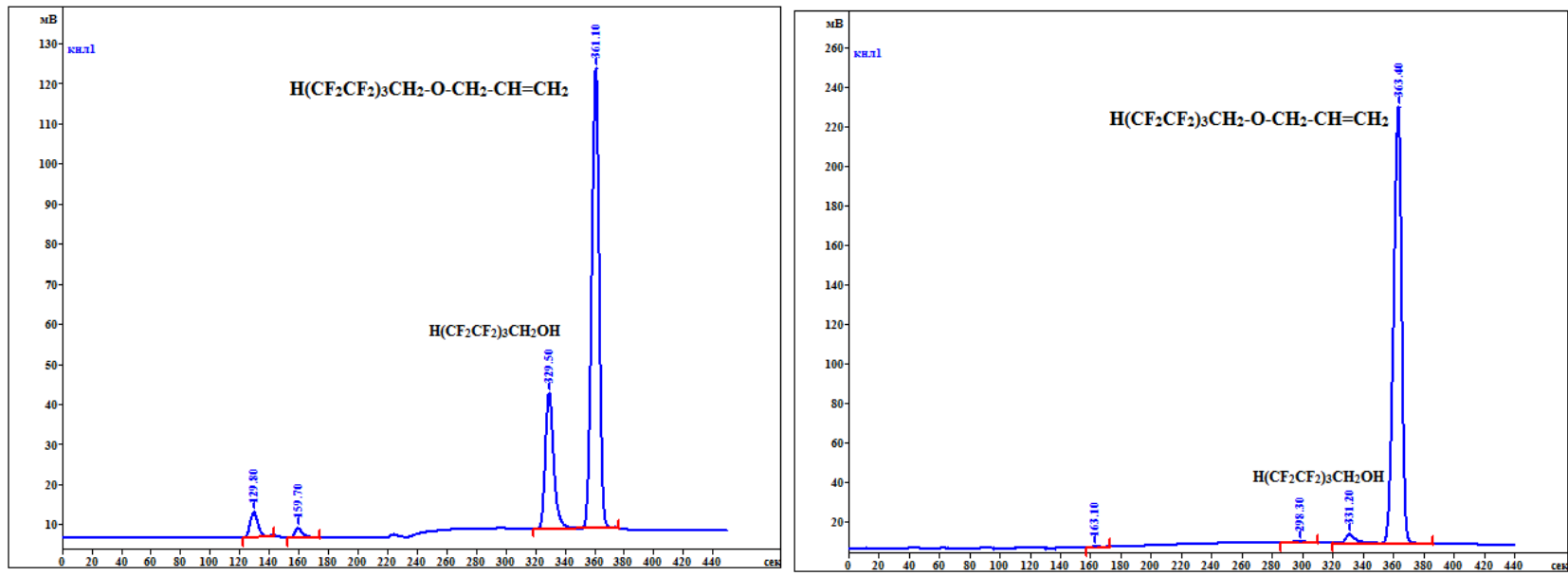

Fig. 6. Chromatogram of 3-(2,2,3,3,4,4,5,5,6,6,7,7-Dodecafluoroheptoxy) propene (If) obtained by method A (left) and method B (right).

\section{Conclusions}

1. A preparative method for producing polyfluoroalkoxypropenes was proposed: the use of an aqueous solution of potassium hydroxide (25-30\%), a $10-20 \%$ excess of allyl halide in relation to polyfluorinated alcohols, the solubiliser is 1,4-dioxane, and the catalyst is TBAB: a) it was found that under the conditions of a heterophasic process, the use of 1,4-dioxane (5-15 vol.\%) as a solubiliser provides a high conversion of fluoroalkanols only in the case of lower alcohols $\left(\mathrm{CF}_{3} \mathrm{CH}_{2} \mathrm{OH},\left(\mathrm{CF}_{3}\right)_{2} \mathrm{CHOH}, \mathrm{HCF}_{2} \mathrm{CF}_{2} \mathrm{CHOH}\right.$, ) with the formation of the end ethers $\left(50-90^{\circ} \mathrm{C}, 4-13\right.$ hours) (yields $72-85 \%)$;

b) it was experimentally established that the use of TBAB shortens the synthesis by 2.5-3 times and 
increases the yields of fluorine-containing allyl ethers (80-94\%);

c) it was shown that the use of a phase transfer catalyst - TBAB, is necessary to achieve the complete conversion of relatively long chain fluoroalkanols $\left(\mathrm{CF}_{3}\left(\mathrm{CF}_{2}\right)_{3} \mathrm{CH}_{2} \mathrm{OH}, \quad \mathrm{H}\left(\mathrm{CF}_{2} \mathrm{CF}_{2}\right)_{2} \mathrm{CH}_{2} \mathrm{OH}\right.$ $\left.\mathrm{H}\left(\mathrm{CF}_{2} \mathrm{CF}_{2}\right)_{3} \mathrm{CH}_{2} \mathrm{OH}, \mathrm{H}\left(\mathrm{CF}_{2} \mathrm{CF}_{2}\right)_{4} \mathrm{CH}_{2} \mathrm{OH}\right)$.

\section{References}

1. R.W. Fasick, J. Newark, S. Ryanolds, USP 3378609 (1968)

2.A.A. Yarosh, S.P. Krukovsky, T.A. Pryakhina, Mendeleev Commun. 16, 190 (2006)

3. A.G. Pittman, W.L. Wasley, USP 3698856 (1972)

4. E. Pechhold, P.M. Murphy, USP 5954493 (1999)

5. M. Hata, J-Y. Yoon, J-H. Hah, Advances in resist technology and processing. 23, 6153 (2006)

6. T. Suzuki, JP 62014860 (1987)

7.A.A. Il'in, A.N. Il'in, Y.L. Bakhmutov, Russ. J. Appl. Chem. 80, 405 (2007)

8. B. Ameduri, B. Bernard, Well-Architectured fluoropolymers: synthesis, properties and applications (1st ed. Elsever, The Boulevard, Langford Lane Kidlington, Oxford, UK, 2004)

9.E. Kissa, Fluorinated surfactants and repellents (2nd ed. Marcel Decker, New York, NY, 2001)

10. Y. Ishimara, JP 09124663 (1997)

11. M. Sangermano, R. Bongiovanni, G. Malucelli, et. al., J. Polym. Sci. 40, 2583 (2002)

12. O.W. Steward and O.R. Pierce, J. Org. Chem. 26, 2947 (1961)

13. A.G. Pittman, W.L. Wasley, USP 3382222

(1967)

14. A.G. Pittman, W.L. Wasley, GBP 1372121

(1974)

15. I.T. Horvath, K.C. Lau, E. Law, USP 20140323672 (2014)

16. B. Boutevin, B. Youssef, J. Fluor. Chem. 35, 399 (1987)

17. A.S. Smith, B.J. Brisdon, S.A. Brewer et. al., J. Mater. Chem. 10, 1765 (2000)

18. L.M. Popova, A.S. Tsyrulnikova, S.V. Vershilov, Fluorine notes. 118, 3 (2018)

19. B.S. Furniss, A.J. Hannaford, P.W.G. Smith, Vogel's Textbook of practical organic chemistry (Wiley, New York, NY, 1989)

20. H. Maciejewski, J. Karasiewicz, B. Marciniec, Polimery. 57, 449 (2012)

21. A.I. Rakhimova, E.V. Shurubtsovab, N. A. Storozhakovaa, Russ. J. Gen. Chem. 77, 345 (2007)

22. A.G. Pittman, B.A. Ludwig, D.L. Sharp, J. Polym. Sci. 6, 1741 (1968)

23. C.A. Audouard, M.R. Garayt, E. Kerouredan et. al., J. Fluor. Chem. 126, 611 (2005)

24. B. Boutevin, P. Yves, USP 4633004 (1986)

25. Z-H. Li, e-Polymers, 3, 1 (2008)

26. B.V. Stolyarov, I.M. Savinov, A.G. Vitenberg, Rukovodstvo $k$ prakticheskim rabotam po gazovoj hromatografii (3rd ed. Himiya, Leningrad, 1988)
27. E.V. Dehmlow, S.S. Demhlow, Phase transfer catalysis (Verlag Chemie, Weinheim, 1983) 